\title{
Interfacial Adhesion Characteristics of Kenaf Fibres Subjected to Different Polymer Matrices and Fibre Treatments
}

\author{
Umar Nirmal, Saijod T. W. Lau, and Jamil Hashim \\ Centre of Advanced Materials and Green Technologies, Faculty of Engineering and Technology, Multimedia University, \\ 75450 Jalan Ayer Keroh Lama, Melaka, Malaysia \\ Correspondence should be addressed to Umar Nirmal; nirmal@mmu.edu.my
}

Received 15 July 2014; Revised 9 October 2014; Accepted 12 October 2014; Published 6 November 2014

Academic Editor: Sandro C. Amico

Copyright (C) 2014 Umar Nirmal et al. This is an open access article distributed under the Creative Commons Attribution License, which permits unrestricted use, distribution, and reproduction in any medium, provided the original work is properly cited.

This study is aimed at determining the interfacial adhesion strength (IAS) of kenaf fibres using different chemical treatments in hydrochloric $(\mathrm{HCl})$ and sodium hydroxide $(\mathrm{NaOH})$ with different concentrations. Single fibre pullout tests (SFPT) were carried out for both untreated and treated fibres partially embedded into three different polymer matrices; polyester, epoxy, and polyurethane $(\mathrm{PU})$ as reinforcement blocks and tested under dry loading conditions. The study revealed that kenaf fibres treated with $6 \% \mathrm{NaOH}$ subjected to polyester, epoxy, and PU matrices exhibits excellent IAS while poor in acidic treatment. The effect of SFPT results was mainly attributed to chemical composition of the fibres, types of fibre treatments, and variation in resin viscosities. By scanning electron microscopy examination of the material failure morphology, the fibres experienced brittle and ductile fibre breakage mechanisms after treatment with acidic and alkaline solutions.

\section{Introduction}

Presently, critical driving forces such as cost, weight reduction coupled with increased emphasis in research on renewable materials has resulted in extensive growing interests on natural fibres for composite applications. This is due to the fact that natural fibres are less costly and have low specific weight and higher strength and stiffness than glass fibre which was previously reported by Gill and Yousif [1]. Liu et al. [2] reported that natural fibres are readily available from renewable sources, where their production requires little energy by taking in $\mathrm{CO}_{2}$ and releasing $\mathrm{O}_{2}$ back to the environment. Furthermore, Joshi et al. [3] and Quig and Dennison [4] revealed that natural fibres possess good thermal and acoustic insulating properties, low in density (i.e., low wear of tooling and no skin irritation), and are producible with low investment. However, Fukuhara [5] stated that natural fibre composites exhibit low environmental impact resistance and are subject to moist degradation that had limited their usage on nonstructural applications. Recent research by Dillon [6] showed that significant improvements of these properties can be attained via appropriate fibre treatment. As a result, treated natural fibre composites are now being used extensively in many structural applications such as natural fibre reinforced car roof and catamaran hull. Moreover, due to overwhelming interest of using natural fibres in the aforesaid, Quig and Dennison [4] and Nirmal et al. [7] have forecasted that there will be a dramatic increase of more than USD \$1634 million potential on the consumption of natural fibre composites in various applications, mainly in aerospace industry, marine sector, automotive industry, sporting segments, and construction industries.

Greater potential on the use of natural fibre composites is apparent with the enhanced performance of treated natural fibres. Many published works done by Aziz and Ansell [8], Aziz et al. [9], John and Thomas [10], McNally and McCord [11], Ray [12], Mwaikambo and Bisanda [13], Yousif and $\mathrm{Ku}$ [14], Alsaeed et al. [15], Shalwan and Yousif [16], Brown [17], Brahmakumar et al. [18], and Kenins [19] have shown that chemical treatments enhanced the mechanical performance of treated natural fibres compared to the untreated ones. In the case of alkaline treatment, Nirmal et al. [20] and Pothan et al. [21] indicated that greater improvements on natural fibre reinforced composites can be attained because of removal of impurities on fibre surface and its lignin (which is hydrophilic), thus exposing more of the cellulosic 
fibre region that allows it to be bonded cohesively with the polymer matrix. Besides, Sgriccia et al. [22] highlighted that silane treatment generally coats the fibre surface which creates a chemical bridge between the natural fibre and the matrix, thereby increasing the bonding strength between the fibre and matrix. Leman et al. [23] and Harper [24] revealed in their work that chemical treatment also reduces the hydrophilic nature of a natural fibre and improves the lifespan by reducing development of fungi. Further than that, Pothan et al. [21] and Torres and Cubillas [25] investigated the effects of chemical treatment using stearic acid on mechanical bonding strength between flax fibre and polypropylene. They concluded that acid treatment modified flax fibre surface but not the fibre bulk.

Other than chemical treatments, attempts were made to enhance mechanical properties of natural fibre reinforced plastic composites by modifying the resin properties. However, very limited work has been carried out in comparing the difference in mechanical properties of natural fibre reinforced with varying resin properties. Cordes and Daniel [26] used four different types of polyester resin to reinforce kenaf fibre. In the study, results showed that modified polyester enables the kenaf fibre to bond firmly with the resin matrix thereby enhancing its mechanical properties of the composite. In the year 2011, Nirmal et al. [20] investigated single fibre pullout test using betelnut reinforced thermosetting composites, namely, epoxy and polyester. Experimental results revealed that epoxy gave better performance compared to polyester resin due to the fact that epoxy has lower viscosity compared to polyester which increased fibre surface wettability and improved fibre bonding with the matrix.

In recent years, more focus has been made in investigating mechanical properties and tribological characteristics using kenaf fibre as the reinforcing agent for composites. Many researchers such as John and Thomas [10], Narish et al. [27], Chin and Yousif [28], Bernard et al. [29], and Nishino et al. [30] evaluated the tribological performance and mechanical properties of treated and untreated kenaf fibre reinforced composites and concluded that the latter had shown excellent alternative to glass fibre composites and metallic composites in specific applications.

From the compilation of work done on kenaf fibre composites by Kim et al. [31], it can be said that the mechanical strength of the composites relies on the content of fibre in the composites (up to $70 \% \mathrm{vol}$ ). Most of the treatments done by researchers such as Leman et al. [23], Harper [24], and Agrawal et al. [32] (i.e., alkaline and silane treatment) were proven to enhance the mechanical properties of composites. In general, mechanical failures of these composites are mostly due to fibre pullout, fibre debonding, and fibre breakage. Based on published works, limited literature is available on the effects of fibre treatment (alkaline and acid) and concentration of chemical treatment on the mechanical properties and interfacial adhesion strength of kenaf fibre. Therefore, this study is necessary in order to evaluate the interfacial adhesion strength between untreated kenaf fibre and chemically treated kenaf fibre impregnated in thermoset (epoxy, polyester) and thermoplastic (polyurethane) matrices at dry loading conditions.
TABLE 1: Chemical composition of kenaf fibres [29].

\begin{tabular}{lc}
\hline Composition & wt.\% \\
\hline Cellulose & $45-57$ \\
Hemicellulose & $20-22$ \\
Lignin & $8-13$ \\
Pectin & $3-5$ \\
\hline
\end{tabular}

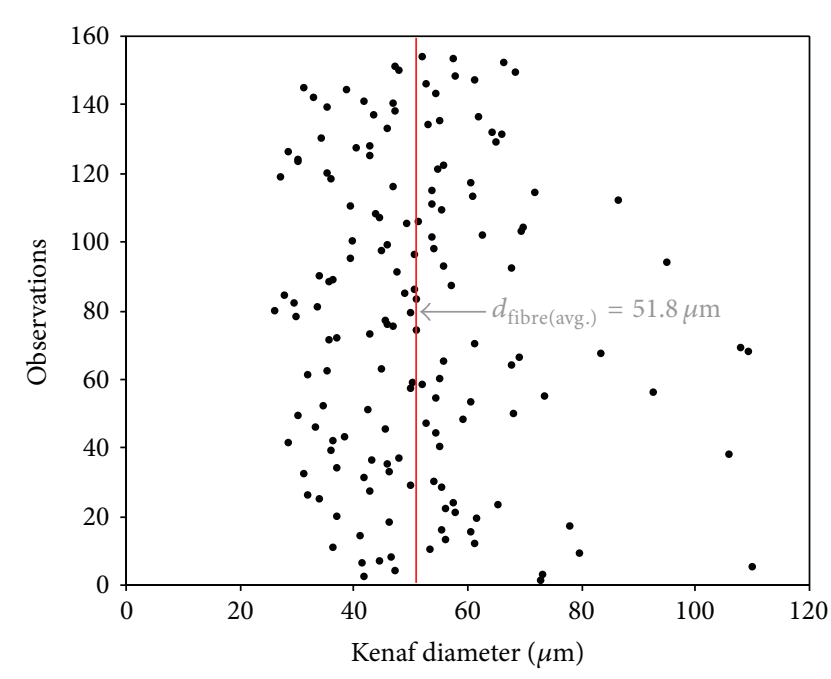

FIGURE 1: Determination of effective average diameter of kenaf fibre.

\section{Materials Preparation}

2.1. Preparation of Fibres. Kenaf fibre (Hibiscus cannabinus L.) used for the current work was obtained from Malaysian Agricultural Research and Development Institute (MARDI). Raw fibres as received contained dust and husk; therefore it was subjected to a thorough cleaning process. Firstly, the raw fibres were dusted in open air before being cleansed by using domestic water to remove the dust and impurities present. This is followed with oven drying for 24 hours at $40^{\circ} \mathrm{C}$. Next, the fibres were gently combed unidirectionally and placed on a clean paper sheet. The cleaned fibres were then separately soaked in sodium hydroxide $(\mathrm{NaOH})$ and hydrochloric acid $(\mathrm{HCl})$ of $4 \%$ and $6 \%$ concentrations, for 12 hours at room temperature. After that, the fibres were taken out from their respective treatments and rinsed using distilled water. The fibres were then dried in oven at $40^{\circ} \mathrm{C}$ for 24 hours. Finally, the untreated and treated fibres were cut to desired lengths $(\sim 100 \mathrm{~mm})$ for test specimen preparations. By means of a $10 \mathrm{X}$ NK Vision microscope, the kenaf diameter was determined from a control sample size containing 160 sets of individual kenaf fibres. Distribution of different kenaf fibre diameters with respect to the number of observations is presented in Figure 1. Based on Figure 1, the average diameter of the kenaf fibre cross section is $51.8 \mu \mathrm{m}$. The chemical composition of kenaf fibres is presented in Table 1 . It is to be noted here that the idea of using $\mathrm{NaOH}$ and $\mathrm{HCl}$ treatment is to explore the possibility to promote high adhesion strength of the kenaf fibre by means of "chemically coupling" the treated fibres to the polymer resin. Although it is generally known that 


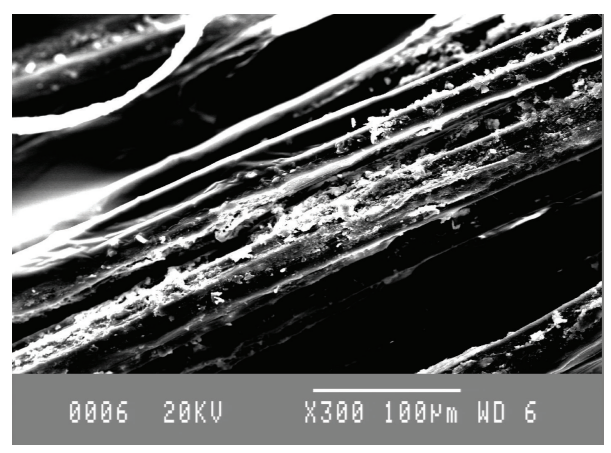

(a) Untreated kenaf fibre

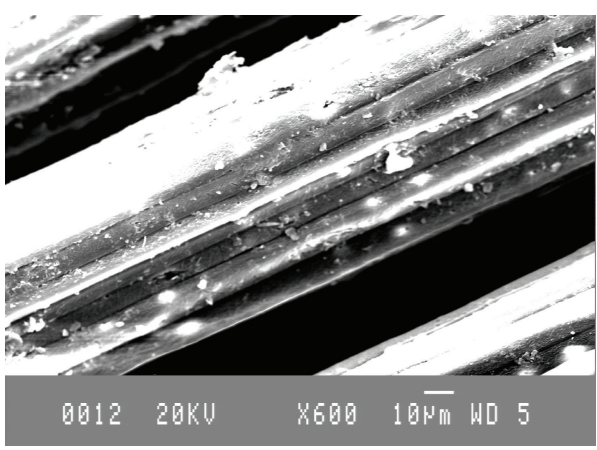

(b) $4 \%-\mathrm{HCL}$

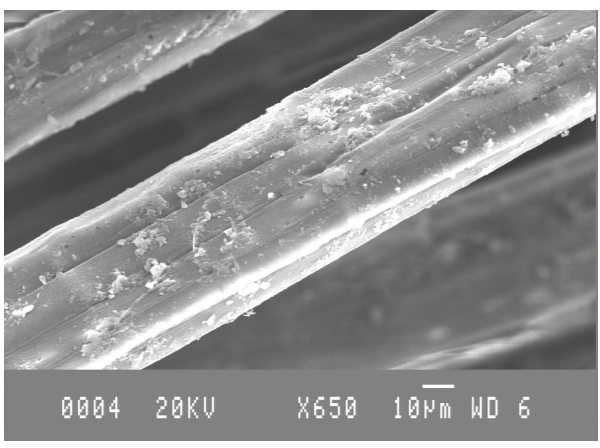

(d) $4 \%-\mathrm{NaOH}$

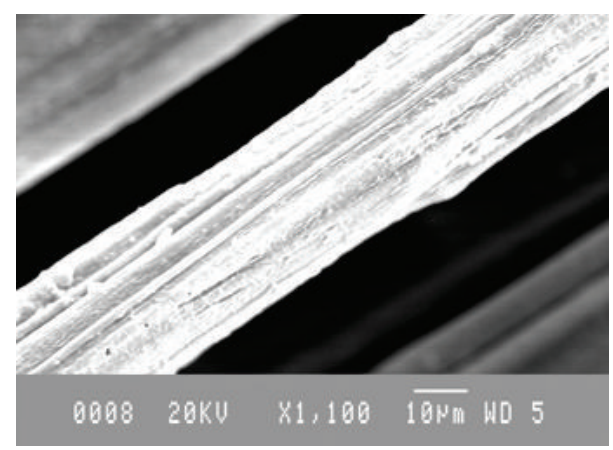

(c) $6 \%-\mathrm{HCL}$

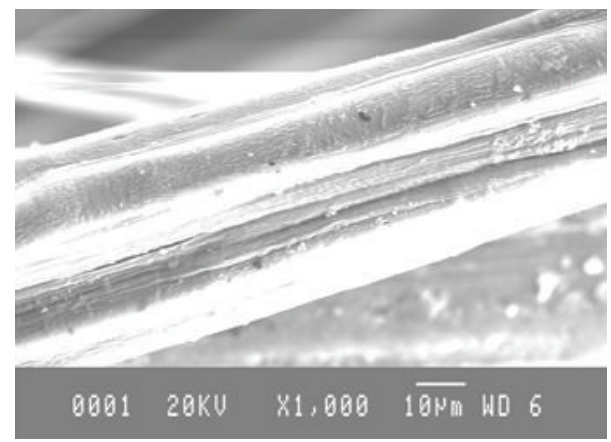

(e) $6 \%-\mathrm{NaOH}$

FIGURE 2: SEM images showing the difference of kenaf fibre texture because of various chemical treatments compared to untreated fibre.

acidic treatment could destroy the natural fibre by means of acidic deterioration, some review works claimed the opposite $[33,34]$.

Micrographs of untreated and treated kenaf fibres are presented in Figures 2(a)-2(e). In Figure 2(a), impurities can be clearly seen on the surface of the untreated fibre although the fibre has been thoroughly cleaned using domestic water. On the other hand, chemically treated fibres in $4 \% \mathrm{HCl}$ and $\mathrm{NaOH}$ (Figures 2(b) and 2(d)) revealed lesser amount of impurities along the surface. Describing possibilities of impurities dissolved in the solution, Figure 2(c) shows the fibre treated in $6 \% \mathrm{HCl}$ solution with evidence of clean but rough surface. Similar results were observed for $6 \% \mathrm{NaOH}$ treated fibres (Figure 2(e)) with clean and smooth outer surface. With $6 \% \mathrm{NaOH}$ treatment, traces of impurities were not observed indicating higher surface area of bonding between fibre and matrix.
2.2. Types of Polymer Resins Used and Their Basic Properties. In the current study, influence of different polymer resin on interfacial adhesion strength was considered. Thermoplastic polyutherene (Mirathane 5117A/B), thermoset polyester (Butanox M-60), and thermoset epoxy (DER 331) resins have been adopted as polymer matrices for the present study. Besides being locally manufactured and easily available, these resins as specified by Nirmal et al. [20], Narish et al. [27], and Nirmal et al. [43] were selected due to their cost effectiveness and wide applications. Table 2 highlights some of the different types of polymers and their main applications.

For thermosetting resin, Butanox M-60 unsaturated polyester resin was mixed with $1.5 \mathrm{wt} \%$ of methyl ethyl ketone peroxide (MEKP). On the other hand, thermoset epoxy used is a liquid reaction product of Epichlorohydrin and Bisphenol-A. The curing agent used was polyamide. The epoxy resin and hardener were mixed uniformly at a weight 


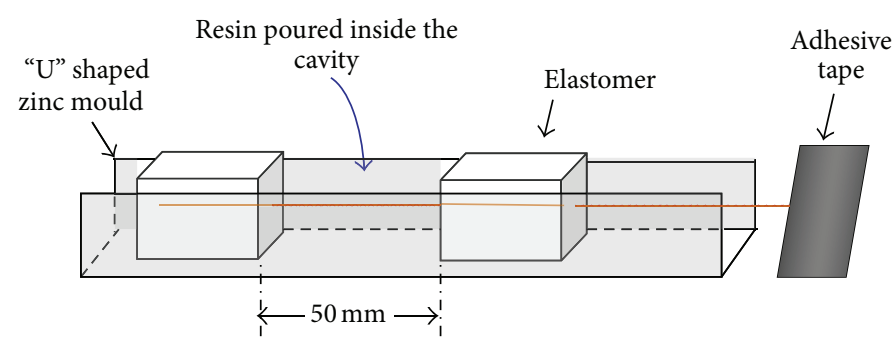

(a) Fabrication method of the pullout test specimens

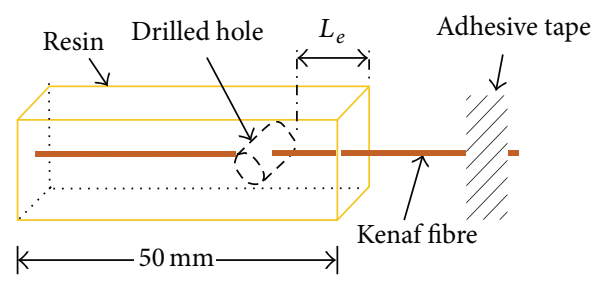

(b) Prepared pullout test specimen

FIgURE 3: (a) Schematic illustration of the mould and (b) corresponding test specimen.

TABLE 2: Types of polymers and their applications.

\begin{tabular}{|c|c|}
\hline \multicolumn{2}{|c|}{ Thermoset polymers } \\
\hline Types & Applications \\
\hline Polyester [35-37] & Composite material/bearing application \\
\hline Epoxides [38-40] & Boat hulls/composite material \\
\hline \multicolumn{2}{|c|}{ Thermoplastic polymers } \\
\hline Types & Applications \\
\hline Polyutherene $[41,42]$ & Name tags/canopies/lenses for car lights \\
\hline
\end{tabular}

TABLE 3: Basic properties of the different types of resin used at $25^{\circ} \mathrm{C}$.

\begin{tabular}{lc}
\hline Polyester & Butanox M-60 \\
\hline Physical state & Liquid \\
Density & $1170 \mathrm{~kg} / \mathrm{m}^{3}$ \\
Viscosity & $25 \mathrm{mPa} \cdot \mathrm{s}$ \\
\hline Epoxy & DER 331 \\
\hline Physical state & Liquid \\
Density & $1100 \mathrm{~kg} / \mathrm{m}^{3}$ \\
Viscosity & $15000 \mathrm{mPa} \cdot \mathrm{s}$ \\
\hline Polyurethane & Mirathane $5117-\mathrm{A} / \mathrm{B}$ \\
\hline Physical state & Liquid \\
Density & $1400 \mathrm{~kg} / \mathrm{m}^{3}$ \\
Viscosity & $5200 \mathrm{mPa} \cdot \mathrm{s}$ \\
\hline
\end{tabular}

ratio of $2: 1$. Concerning thermoplastic resin, Mirathane 5117-A was adopted. The resin was mixed uniformly with hardener (Mirathane 5117-B) at a mixing ratio of $100: 35$ by weight percentage. Information of the three polymer resins used is listed in Table 3.

2.3. Preparation of Composite. Interfacial adhesion composites were fabricated according to established research methods for fibre pullout test done by Quek and Yue [44], Wong et al. [35], and Valadez-Gonzalez et al. [36]. Firstly, a " $U$ " shaped zinc channel with cross section dimensions of $25.4 \mathrm{~mm} \times 25.4 \mathrm{~mm}$ was used as a mould. Using elastomers cut to size with the width of zinc mould, a small hole insertion was made through the centre of each of the elastomers. Next, the mould inner walls were sprayed with a layer of a release agent. Then, kenaf fibres from the control sample size (cf. Figure 1) were carefully inserted into the holes made through the elastomer using tweezers and the whole set-up was placed into the zinc mould as illustrated in Figure 3(a). It is to be noted here that the kenaf fibre diameters vary largely as it is derived naturally. Hence, to control (i.e., minimize the fibre diameter variation) the fibre's diameter, the fibres were selected from the control sample size containing 160 individual kenaf fibres. Finally, resin was poured into the mould cavity and allowed to cure at $26 \pm 2^{\circ} \mathrm{C}$ for 24 hours before further curing in an oven for 12 hours at $40^{\circ} \mathrm{C}$. Lastly, a hole of $6 \mathrm{~mm}$ in diameter is drilled through the block at determined distance from the edge $\left(L_{e}=20 \mathrm{~mm}\right)$. This was done to cut off the fibre length embedded in the resin where the effective fibre length for the pullout test was set at $20 \mathrm{~mm}$. Figure 3(b) gives a schematic illustration of prepared pullout test specimens.

\section{Experimental Procedure}

Single fibre pullout tests (SFPT) were performed using the universal test system (1000Q Standalone) shown in Figure $4(\mathrm{a})$, with a loading speed of $1 \mathrm{~mm} / \mathrm{min}$. Yousif et al. [37] indicated that the accuracy of the machine is $70.5 \%$ of reading from full scale to $0.2 \%$ load cell capacity per ASTM E4 and $0.1 \%$ of setting $(0.05 \%$ at $10 \mathrm{in} / \mathrm{min})$.

SFPT was carried out to determine the interfacial adhesion characteristics between untreated and treated kenaf fibre embedded in different polymer matrix. Figure 4(b) gives an illustration of the direction of loading force, with test specimens firmly clamped together using the jaw clamps. Experiments were conducted under room temperature conditions and each test was repeated five times before the average results were tabulated. Interfacial adhesion strength $\left(\tau_{i}\right)$ for current study was determined using

$$
\tau_{i}=\frac{F_{\text {debonding }(\max )}}{d_{\text {fibre }} \times \pi \times L_{e}},
$$

where $\tau_{i}=$ interfacial adhesion strength, $F_{\text {debonding }(\max )}=$ maximum force just before debonding occurs (refer Figure 5), $d_{\text {fibre }}=$ corresponding fibre's diameter measured in $\mu \mathrm{m}, L_{e}=$ $20 \pm 0.05 \mathrm{~mm}$.

\section{Results and Discussions}

The corresponding results on the average maximum debonding force of the kenaf fibre subjected to different types of 


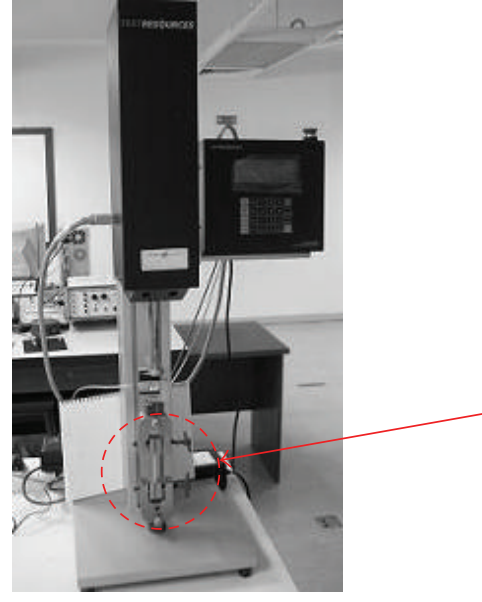

(a)

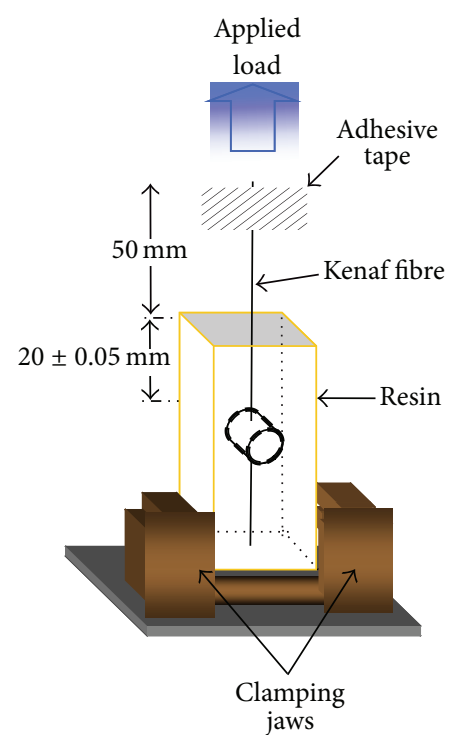

(b)

FIGURE 4: (a) Universal test machine; (b) schematic illustration of test specimen and direction of loading force for an IAS test.

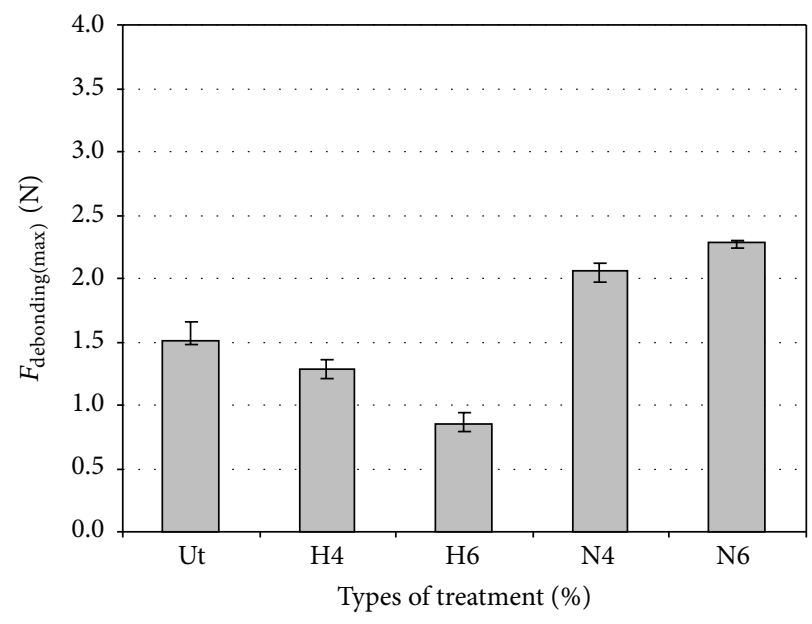

(a) Polyester

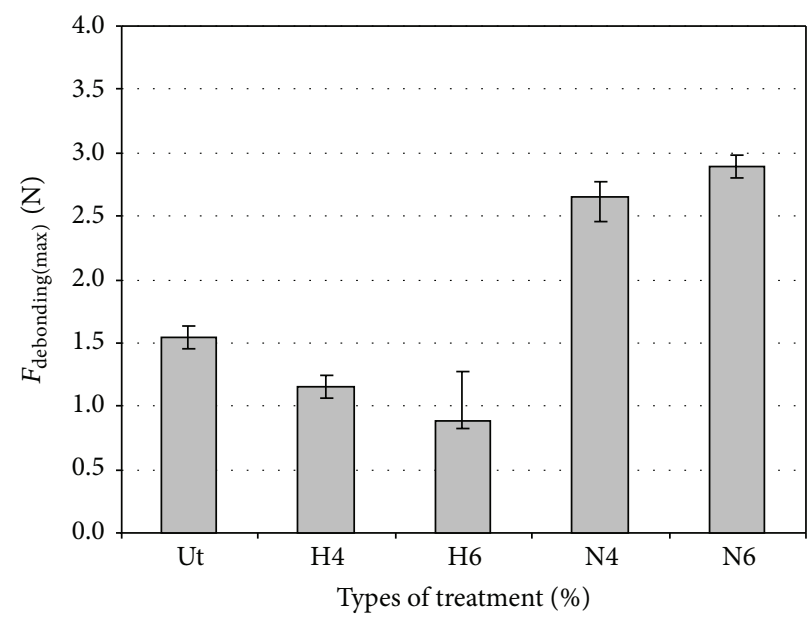

(b) Epoxy

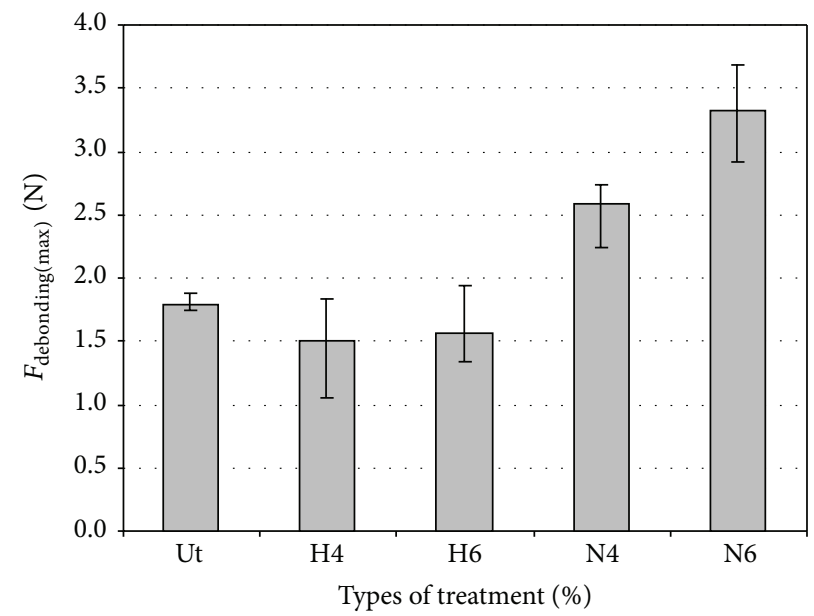

(c) Polyurethane

FiguRE 5: Average maximum debonding force $\left(F_{\mathrm{d}}\right)$ for untreated (Ut) and treated kenaf fibre subjected to different polymer resins. Remark: $\mathrm{H}$ : hydrochloric acid, $\mathrm{N}$ : sodium hydroxide. 


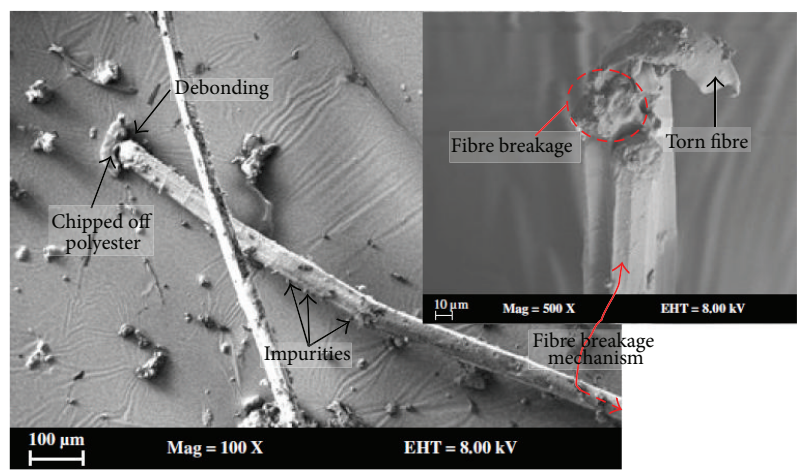

(a) Polyester-Ut

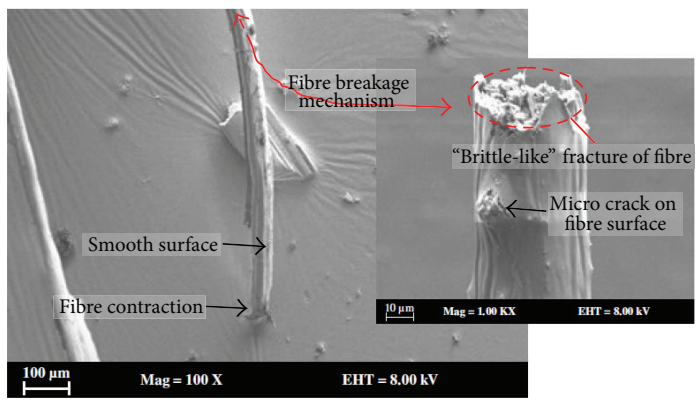

(c) Polyester-H6

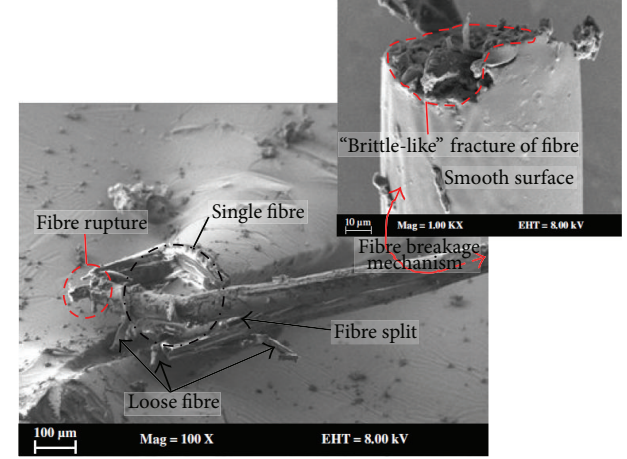

(b) Polyester-H4

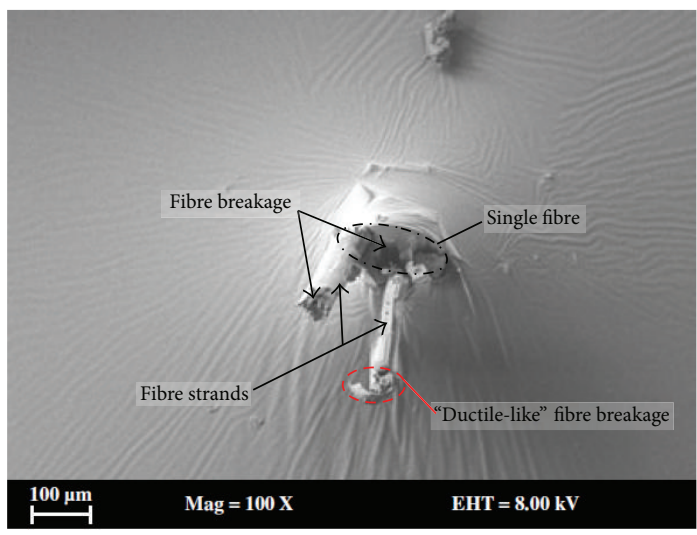

(e) Polyester-N6

FIGURE 6: Corresponding SEM images after the pullout test for untreated and treated kenaf fibre using polyester as the resin.

chemical treatments and matrices are presented in Figures $5(\mathrm{a})-5(\mathrm{c})$.

4.1. Effect of Fibre Treatments. In general, Figure 5 indicates that the $6 \% \mathrm{NaOH}$ treated kenaf fibre recorded the highest debonding force before fibre breakage/debonding for all the different types of matrices (i.e., polyester, epoxy, and polyurethane). This is followed by the $4 \% \mathrm{NaOH}$ treated kenaf fibre, which yields the second highest average load. Remarkably, the maximum debonding force was low for all different matrices when the fibres were treated with $\mathrm{HCl}$. There was a significant drop on the maximum debonding force with higher $\mathrm{HCl}$ concentration $(6 \% \mathrm{HCl})$. In summary, $6 \% \mathrm{NaOH}$ fibre treatment served to boost the average maximum debonding force by $51.6 \%, 86.6 \%$, and $86.1 \%$, with the kenaf fibre embedded in polyester, epoxy, and

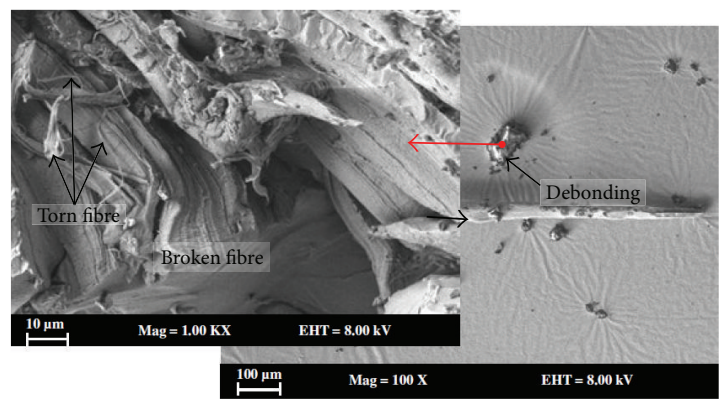

(d) Polyester-N4 polyurethane matrices, respectively, compared to untreated fibre. On the contrary, $6 \% \mathrm{HCl}$ has worsened average maximum debonding force. The debonding force was decreased by $43 \%, 42.5 \%$, and $11.9 \%$ subjected to polyester, epoxy, and polyurethane matrices, respectively, compared to untreated fibre. The treatment with $6 \% \mathrm{NaOH}$ resulted in the highest value of IAS because of a complete removal of impurities on the kenaf fibre outer surfaces, hence increasing fibre surface roughness, which is crucial during fabricating of SFPT specimens (i.e., enhanced surface wettability of the fibre/matrix). From a reported work by Khan et al. [38], the residue on the fibre is the major reason in reducing the bonding strength between fibre and resin. Furthermore, Aziz and Ansell [8] and Aziz et al. [9] confirmed in their work that the effect of alkaline treatment on kenaf fibres served to boost the mechanical properties of the composites as compared to 


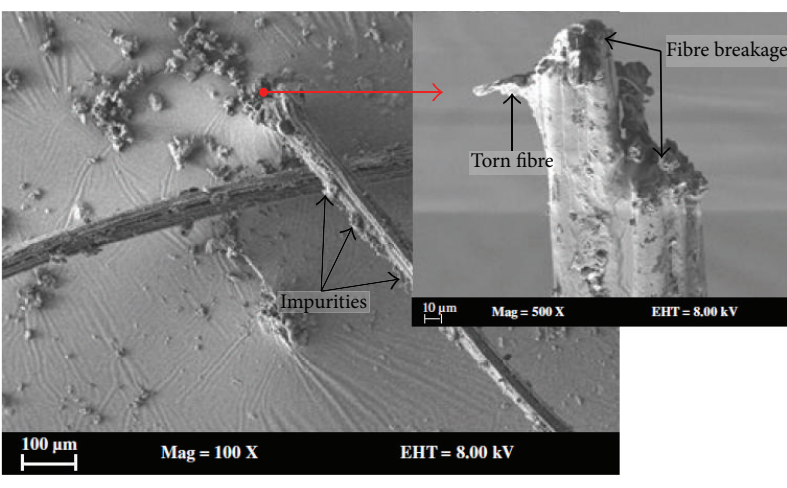

(a) Epoxy-Ut

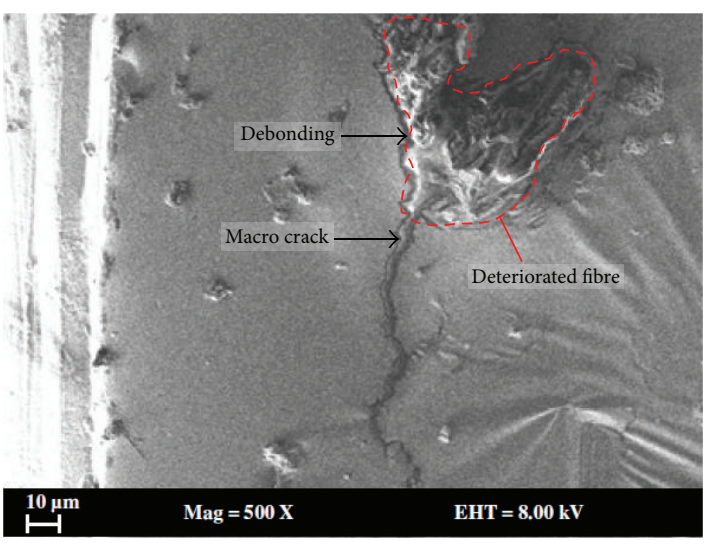

(c) Epoxy-H6

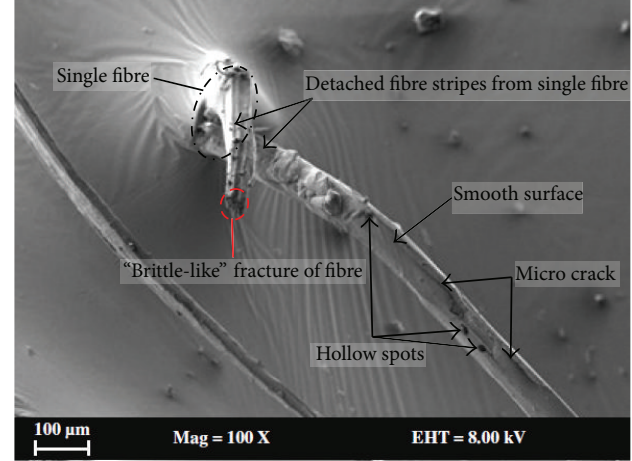

(b) Epoxy-H4

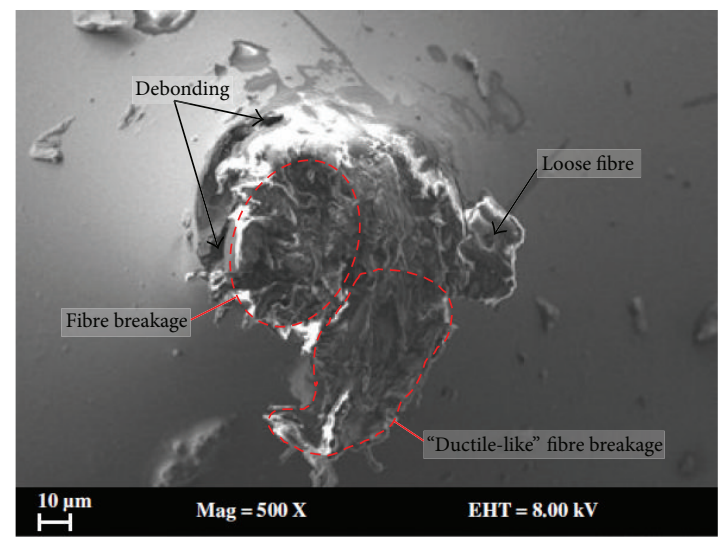

(d) Epoxy-N4

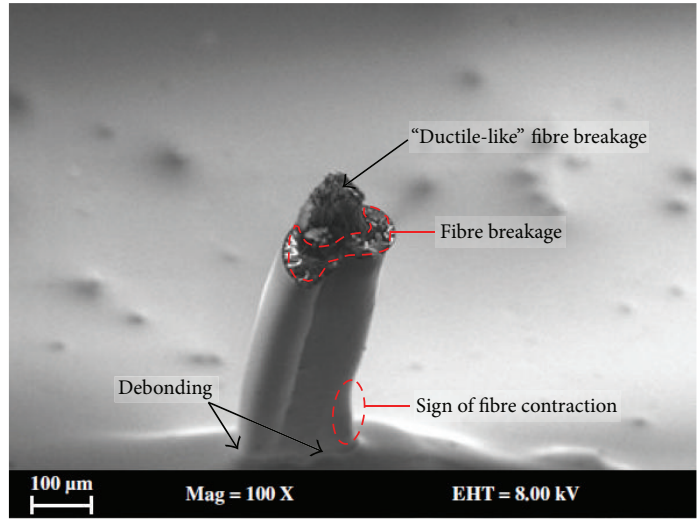

(e) Epoxy-N6

FIGURE 7: Corresponding SEM images after the pullout test for untreated and treated kenaf fibre using epoxy as the resin.

the untreated fibres. Moreover, Aziz and Ansell [8], Aziz et al. [9], Huda et al. [39], Yousif and El-Tayeb [40], and Rokbi [41] revealed that alkaline treatment can remove impurities and lignocellulosic wax present on the fibre surface. It was also reported by Aziz and Ansell [8], Aziz et al. [9], Quek and Yue [44], and Oláh and Vancso [42] that alkaline treatment had the potential to improve interfacial adhesion strength between natural fibres and resin matrix, reduce composite porosity, and enhance wear performance of the composite. However, acidic treatment $(4 \%$ and $6 \% \mathrm{HCl})$ on kenaf fibres did not improve IAS of the fibre/matrix. This could be because of the high delamination rate on the outer surfaces of the kenaf fibre (cf. Figures 2(b) and 2(c)). More explanations on the IAS will be discussed in Section 4.2 with the assistance of the SEM images.

4.2. Observation of SEM Morphology. The corresponding SEM images after the pullout test for the untreated and treated kenaf fibre at different fibre treatments subjected to polyester, epoxy, and PU resins are shown in Figures 68 , respectively. Before taking the micrographs, the pullout samples were coated with a thin layer of gold by using an 


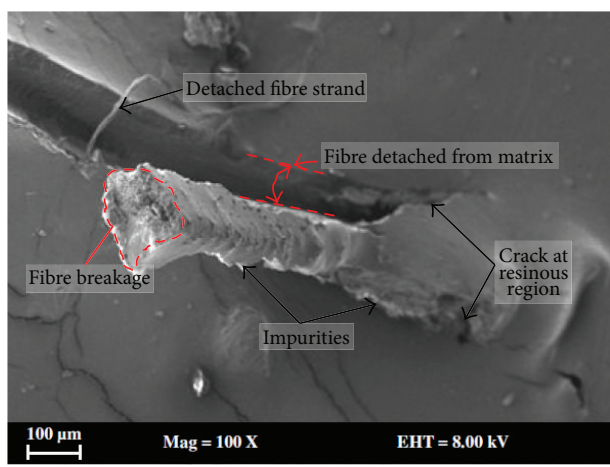

(a) PU-Ut

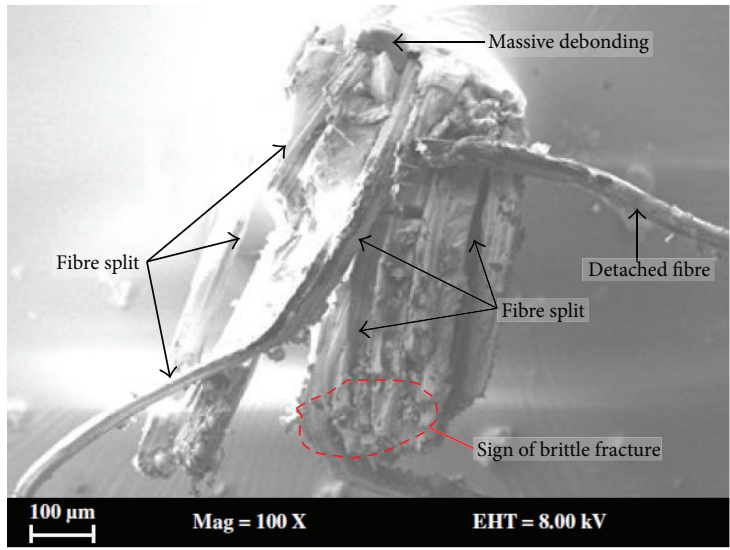

(c) PU-H6

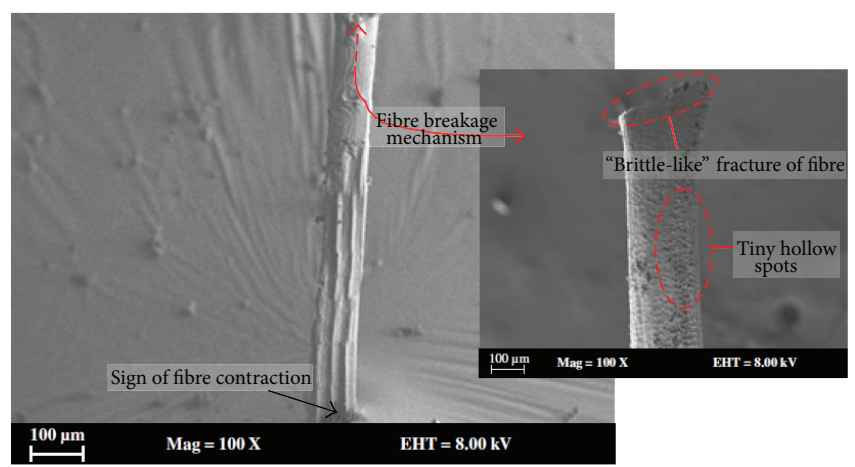

(b) PU-H4

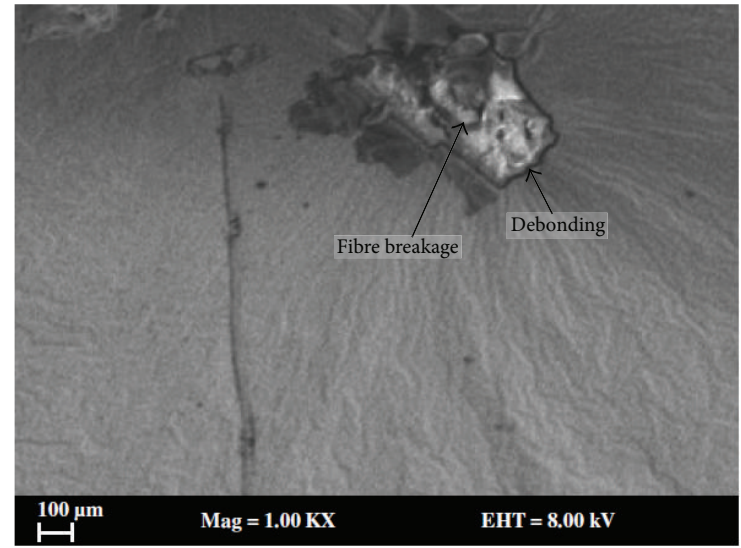

(d) PU-N4

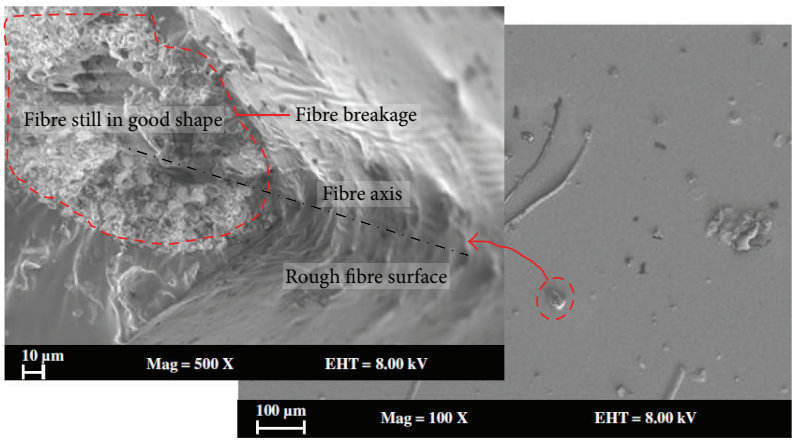

(e) PU-N6

FIGURE 8: Corresponding SEM images after the pullout test for untreated and treated kenaf fibre using polyurethane (PU) as the resin.

ion sputtering model: JEOL, JFC-1600. The samples were analyzed by SEM machine model: EVO 50 ZEISS-7636. All observing conditions were performed at room temperature of $28 \pm 5^{\circ} \mathrm{C}$ and at humidity level of $80 \pm 10 \%$. Tables 4,5 , and 6 summarize the comparison of SFPT in polyester, epoxy, and $\mathrm{PU}$ resin, respectively.

Figure 6 illustrates the micrograph images of single kenaf fibre subjected to polyester resin at different treatments. From the figure, effect of acidic and alkaline treatment has changed the properties of the fibre's surface. Brittle-like fracture was observed after the pullout test when the fibre was treated with $\mathrm{HCl}$ treatment. For alkaline treatment, the pullout samples exhibited a ductile-like fracture. For the untreated samples, debonding of the fibre against the matrix is evidenced. Similar sign of defects can be seen when the fibres were subjected to epoxy resin for the untreated and treated samples; compare Figure 7. Figure 8 illustrates the SEM images of the untreated and treated samples after the pullout tests subjected to PU resin. Generally, it is observed that the untreated samples exhibited fibre breakage after the pullout test associated with slight fibre pullout. This fibre pullout could be due to the impurities on the fibre surfaces which lowered the surface wettability of the fibre against the resin matrix, that is, low IAS. When the fibres were treated with $\mathrm{HCl}$, a brittle-like fracture was evidenced at the end of the fibre after the pullout. There was evidence of tiny hollow spots and deformed fibre 
TABLE 4: Main fibre pullout mechanisms and their brief remarks for the different types of fibre treatments used subjected to polyester matrix at dry loading conditions.

\begin{tabular}{|c|c|c|c|}
\hline \multicolumn{4}{|l|}{ 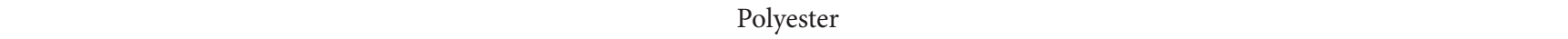 } \\
\hline $\begin{array}{l}\text { Corresponding SEM } \\
\text { figure }\end{array}$ & $\begin{array}{c}\text { Fibre } \\
\text { treatment }\end{array}$ & Brief remark/explanation & Main fibre pullout mechanism \\
\hline Figure 6(a) & Untreated & $\begin{array}{l}\text { Debonding of fibre observed associated with slight } \\
\text { chipping of polyester because of impurities on fibre } \\
\text { surfaces }\end{array}$ & $\begin{array}{l}\text { Fibre breakage associated with slight torn } \\
\text { fibre from the core of the fibre }\end{array}$ \\
\hline Figure 6(b) & $4 \% \mathrm{HCl}$ & $\begin{array}{l}\text { (i) Sign of fibre rupture from the core of the fibre after } \\
\text { the pullout } \\
\text { (ii) Tendency of fibre to split from the main single fibre } \\
\text { was high which contributed to many loose fibres } \\
\text { (iii) Fibre surfaces were smooth which ruined the } \\
\text { interfacial adhesion strength of the fibre against the } \\
\text { matrix }\end{array}$ & $\begin{array}{l}\text { Brittle-like fracture at end of fibre was } \\
\text { observed because of the acidic treatment }\end{array}$ \\
\hline Figure 6(c) & $6 \% \mathrm{HCl}$ & $\begin{array}{l}\text { (i) Sign of fibre contraction during the SFPT } \\
\text { (ii) Fibre surfaces were smooth which lowered the IAS } \\
\text { of the fibre and matrix } \\
\text { (iii) Sign of micro cracks on fibre surfaces which cause } \\
\text { the fibre to break during the pullout test }\end{array}$ & $\begin{array}{l}\text { Brittle-like fracture at end of fibre was } \\
\text { observed because of the acidic treatment }\end{array}$ \\
\hline Figure $6(\mathrm{~d})$ & $4 \% \mathrm{NaOH}$ & $\begin{array}{l}\text { (i) Slight debonding of fibre with matrix } \\
\text { (ii) Fibre was torn apart from the main core fibre after } \\
\text { the test indicating high interlocking capabilities of the } \\
\text { fibre and matrix }\end{array}$ & Pure fibre breakage \\
\hline Figure 6(e) & $6 \% \mathrm{NaOH}$ & $\begin{array}{l}\text { Evidence of many fibre strands from the core of the } \\
\text { fibre indicating that the fibre resisted the pullout force } \\
\text { during the test }\end{array}$ & $\begin{array}{l}\text { Ductile-like breakage was observed at the } \\
\text { end of the fibre }\end{array}$ \\
\hline
\end{tabular}

TABLE 5: Main fibre pullout mechanisms and their brief remarks for the different types of fibre treatments used subjected to epoxy matrix at dry loading conditions.

\begin{tabular}{|c|c|c|c|}
\hline \multicolumn{4}{|c|}{ Epoxy } \\
\hline $\begin{array}{l}\text { Corresponding SEM } \\
\text { figure }\end{array}$ & $\begin{array}{l}\text { Fibre } \\
\text { treatment }\end{array}$ & Brief remark/explanation & Main fibre pullout mechanism \\
\hline Figure 7(a) & Untreated & $\begin{array}{l}\text { High amount of impurities observed on the fibre } \\
\text { surfaces which significantly lowered the IAS of the fibre } \\
\text { and matrix }\end{array}$ & $\begin{array}{l}\text { Fibre breakage associated with mild torn } \\
\text { fibre }\end{array}$ \\
\hline Figure 7(b) & $4 \% \mathrm{HCl}$ & $\begin{array}{l}\text { (i) Fibre stripes were easily detached from the core } \\
\text { main fibre because of the hollow spots on fibre surfaces } \\
\text { which contributed to stress concentrations during SFPT } \\
\text { causing severe micro cracks on fibre surface } \\
\text { (ii) Relatively smooth fibre surfaces after the treatment } \\
\text { which did not contribute to any improvement in IAS of } \\
\text { the fibre against the matrix }\end{array}$ & $\begin{array}{l}\text { Brittle-like fracture at end of fibre was } \\
\text { observed because of the acidic treatment }\end{array}$ \\
\hline Figure 7(c) & $6 \% \mathrm{HCl}$ & $\begin{array}{l}\text { (i) Massive debonding of fibre associated with macro } \\
\text { crack at the resinous region indicating that fibre could } \\
\text { not even withstand the low pullout force (less than } \\
0.8 \mathrm{~N} \text { ) } \\
\text { (ii) Fibre easily ruptured because of high acidic } \\
\text { treatment }\end{array}$ & $\begin{array}{l}\text { Deteriorated fibre at the end of fibre } \\
\text { breakage }\end{array}$ \\
\hline Figure 7(d) & $4 \% \mathrm{NaOH}$ & $\begin{array}{l}\text { (i) Slight debonding of fibre was observed associated } \\
\text { with some loose fibre detached from the main core fibre } \\
\text { indicating that the fibre could withstand the high } \\
\text { pullout force } \\
\text { (ii) Rough fibre surfaces }\end{array}$ & $\begin{array}{l}\text { Ductile-like breakage was observed at the } \\
\text { end of the fibre }\end{array}$ \\
\hline Figure 7(e) & $6 \% \mathrm{NaOH}$ & $\begin{array}{l}\text { Slight debonding of fibre associated with severe signs of } \\
\text { fibre contractions which denotes that the fibre could } \\
\text { withstand the increment in pullout force (more than } \\
2 \mathrm{~N} \text { ) during SFPT }\end{array}$ & $\begin{array}{l}\text { Ductile-like breakage was observed at the } \\
\text { end of the fibre }\end{array}$ \\
\hline
\end{tabular}


TABLE 6: Main fibre pullout mechanisms and their brief remarks for the different types of fibre treatments used subjected to polyurethane matrix at dry loading conditions.

\begin{tabular}{|c|c|c|c|}
\hline \multicolumn{4}{|l|}{ 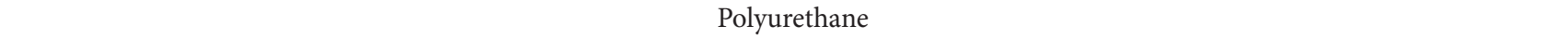 } \\
\hline $\begin{array}{l}\text { Corresponding SEM } \\
\text { figure }\end{array}$ & $\begin{array}{l}\text { Fibre } \\
\text { treatment }\end{array}$ & \multirow{2}{*}{$\begin{array}{l}\text { Brief remark/explanation } \\
\text { (i) Fibre was detached from matrix which caused } \\
\text { several fibre strands still embedded in the matrix } \\
\text { (ii) Sign of impurities on fibre surfaces which could } \\
\text { have caused severe crack at the resinous region during } \\
\text { the pullout (i.e., the impurities on the fibre surfaces } \\
\text { were forced out from the matrix) }\end{array}$} & Main fibre pullout mechanism \\
\hline Figure $8(a)$ & Untreated & & Fibre breakage with slight pullout \\
\hline Figure $8(b)$ & $4 \% \mathrm{HCl}$ & $\begin{array}{l}\text { (i) Sign of low fibre contraction and deformed fibre } \\
\text { surfaces due to the treatment } \\
\text { (ii) Many tiny hollow spots on fibre surfaces which } \\
\text { caused several weak points (i.e., stress concentrations) } \\
\text { during the pullout }\end{array}$ & $\begin{array}{l}\text { Brittle-like fracture at end of fibre was } \\
\text { observed because of the acidic treatment }\end{array}$ \\
\hline Figure 8(c) & $6 \% \mathrm{HCl}$ & $\begin{array}{l}\text { (i) Massive debonding associated with high amount of } \\
\text { fibre split from the main core fibre } \\
\text { (ii) Fibre could easily get detached as it was brittle after } \\
\text { the treatment } \\
\text { (iii) However, the signs of fibre splits also showed that } \\
\text { the fibre resisted the pullout force when it was } \\
\text { embedded in PU as the matrix }\end{array}$ & Torn fibre and slight fibre pullout \\
\hline Figure $8(\mathrm{~d})$ & $4 \% \mathrm{NaOH}$ & Slight debonding of fibre was seen at the resinous region & Pure fibre breakage \\
\hline Figure 8(e) & $6 \% \mathrm{NaOH}$ & $\begin{array}{l}\text { (i) A rough fibre surface was observed after the } \\
\text { treatment which resisted the fibre from pulling out } \\
\text { from the matrix } \\
\text { (ii) End of fibre breakage was still in good shape } \\
\text { indicating that the fibre could withstand the high } \\
\text { pullout force (more than } 3 \mathrm{~N} \text { ), thus increasing the IAS } \\
\text { of the fibre and matrix }\end{array}$ & Pure fibre breakage \\
\hline
\end{tabular}

surfaces which could be the reason why acidic treatment has degraded the IAS properties of fibre. For the case of alkaline treatment, pure fibre breakage was evidence after the pullout test. The evidence from the SEM images suggests that the end of fibre breakage region was still in good shape indicating that the fibre could withstand the high pullout force. More details on the fibre pullout mechanisms and their explanation are provided in Tables 4-6 respectively.

In summary, comparison of IAS with different kenaf fibre treatment as compared to the untreated ones subjected to different types of matrices is presented in Table 7. From the table, positive $(+)$ sign denotes improvement in IAS while negative $(-)$ sign showed degradation of IAS of the fibre at their respective treated conditions compared to the untreated fibre. It can be seen that the improvement of IAS followed the order of $\mathrm{N} 6>\mathrm{N} 4>\mathrm{H} 4>>>\mathrm{H} 6$ for polyester and epoxy matrices; $6 \%$ of $\mathrm{NaOH}$ fibre treatment demonstrated excellent improvement in IAS of the fibre/matrix while $6 \% \mathrm{HCl}$ fibre treatment gave the worst IAS properties. However, when the fibre was embedded in PU, the IAS followed the order of N6 > N4 >>> H6 > H4. The slight difference in the order of IAS could have been owing to the type of resin used during the SFPT. Therefore, more investigations on the chemical analysis of the fibre and different types of treatments and resin used are proposed in future works.
TABLE 7: Improvement in IAS for the different treated kenaf fibre when compared to the untreated kenaf fibres subjected to the different matrices.

\begin{tabular}{lcccc}
\hline & $\mathrm{H} 4$ & $\mathrm{H} 6$ & $\mathrm{~N} 4$ & $\mathrm{~N} 6$ \\
\hline \multirow{2}{*}{ Polyester } & $-15 \%$ & $-43 \%$ & $+37 \%$ & $+52 \%$ \\
& $(3 \%)$ & $(4 \%)$ & $(3 \%)$ & $(4 \%)$ \\
\hline \multirow{2}{*}{ Epoxy } & $-25 \%$ & $-43 \%$ & $+71 \%$ & $+87 \%$ \\
& $(4 \%)$ & $(4 \%)$ & $(4 \%)$ & $(3 \%)$ \\
\hline \multirow{2}{*}{ Polyurethane } & $-16 \%$ & $-12 \%$ & $+45 \%$ & $+86 \%$ \\
& $(3 \%)$ & $(3 \%)$ & $(3 \%)$ & $(4 \%)$ \\
\hline
\end{tabular}

Note. All values in brackets represent the corresponding standard deviations as a result of repeating the measurements for five times.

It is interesting to compare the current work with similar work done by Nirmal et al. [20] using betelnut fibres. In that work, IAS of betelnut fibres treated with N6 increased by about $141 \%$ and $115 \%$ when the fibres were embedded in polyester and epoxy resins, respectively, compared to the untreated ones. Meanwhile, IAS decreased by about $4 \%$ and $33 \%$ when the fibres were treated with $\mathrm{H} 6$ and embedded in polyester and epoxy resins compared to the untreated ones. When mapping these findings to the current work, it is noted that a much higher IAS is attainable using betelnut fibres as 
compared to kenaf fibres; that is, IAS of betelnut fibres treated in N6 was improved by about 2.8 times and 1.3 times when the fibres were embedded in polyester and epoxy resins compared to kenaf fibres embedded in the same type of resins. This could be because of the absence of trichomes at the outer surfaces of the kenaf fibres which lowered the interlocking mechanisms between the fibre and resin. This is confirmed by the SEM image in Figure 2(e) indicating that the outer surfaces of the treated kenaf fibres were relatively smooth which contributed to the low surface wettability against the polymer resin during the pullout process.

\section{Conclusion}

SFPT for untreated and treated kenaf fibres embedded in three different types of matrices were carried out. From the work, a few conclusions can be drawn.

(a) Kenaf fibres treated with $6 \% \mathrm{NaOH}$ gave better IAS of about $51.6 \%, 86.6 \%$, and $86.1 \%$ subjected to polyester, epoxy, and polyurethane matrices, while the interest of treating the fibres with $4 \%$ and $6 \%$ of $\mathrm{HCl}$ solution worsens the IAS of the fibre/matrix for the same types of matrices when compared to the untreated fibres.

(b) By SEM observation, impurities on untreated kenaf fibres had weakened the bonding strength between the fibres and the resins. Macrocracks associated with debonding of fibre were observed after the test.

(c) A "brittle-like" fibre breakage was observed when the kenaf fibres were treated with $4 \%$ and $6 \% \mathrm{HCl}$ solution while a "ductile-like" fibre breakage was observed when the fibres were treated with $4 \%$ and $6 \%$ of $\mathrm{NaOH}$ solution, respectively.

\section{Conflict of Interests}

The authors declare that there is no conflict of interests regarding the publication of this paper.

\section{References}

[1] N. S. Gill and B. F. Yousif, "Wear and frictional performance of betelnut fibre-reinforced polyester composite," Proceedings of the Institution of Mechanical Engineers, Part J: Journal of Engineering Tribology, vol. 223, no. 2, pp. 183-194, 2009.

[2] W. Liu, A. K. Mohanty, P. Askeland, L. T. Drzal, and M. Misra, "Influence of fiber surface treatment on properties of Indian grass fiber reinforced soy protein based biocomposites," Polymer, vol. 45, no. 22, pp. 7589-7596, 2004.

[3] S. V. Joshi, L. T. Drzal, A. K. Mohanty, and S. Arora, "Are natural fiber composites environmentally superior to glass fiber reinforced composites?" Composites Part A: Applied Science and Manufacturing, vol. 35, no. 3, pp. 371-376, 2004.

[4] J. B. Quig and R. W. Dennison, "The complementary nature of fibers from natural and from synthetic polymers," Textile Research Journal, vol. 24, pp. 361-373, 1954.

[5] M. Fukuhara, "Innovation in polyester fibers: from silk-like to new polyester," Textile Research Journal, vol. 63, no. 7, pp. 387391, 1993.
[6] J. H. Dillon, "Current problems and future trends in synthetic fibers," Textile Research Journal, vol. 23, pp. 298-312, 1953.

[7] U. Nirmal, J. Hashim, S. T. W. Lau, Y. My, and B. F. Yousif, "Betelnut fibres as an alternative to glass fibres to reinforce thermoset composites: a comparative study," Textile Research Journal, vol. 82, no. 11, pp. 1107-1120, 2012.

[8] S. H. Aziz and M. P. Ansell, "The effect of alkalization and fibre alignment on the mechanical and thermal properties of kenaf and hemp bast fibre composites: Part 1. polyester resin matrix," Composites Science and Technology, vol. 64, no. 9, pp. 1219-1230, 2004.

[9] S. H. Aziz, M. P. Ansell, S. J. Clarke, and S. R. Panteny, "Modified polyester resins for natural fibre composites," Composites Science and Technology, vol. 65, no. 3-4, pp. 525-535, 2005.

[10] M. J. John and S. Thomas, "Biofibres and biocomposites," Carbohydrate Polymers, vol. 71, no. 3, pp. 343-364, 2008.

[11] J. P. McNally and F. A. McCord, "Cotton quality study," Textile Research Journal, vol. 30, pp. 715-751, 1960.

[12] L. G. Ray, "The role of synthetic fibers in the textile industry of the future," Textile Research Journal, vol. 22, pp. 144-151, 1952.

[13] L. Y. Mwaikambo and E. T. N. Bisanda, "Performance of cottonkapok fabric-polyester composites," Polymer Testing, vol. 18, no. 3, pp. 181-198, 1999.

[14] B. F. Yousif and H. Ku, "Suitability of using coir fiber/polymeric composite for the design of liquid storage tanks," Materials and Design, vol. 36, pp. 847-853, 2012.

[15] T. Alsaeed, B. F. Yousif, and H. Ku, "The potential of using date palm fibres as reinforcement for polymeric composites," Materials \& Design, vol. 43, pp. 177-184, 2013.

[16] A. Shalwan and B. F. Yousif, "In state of art: mechanical and tribological behaviour of polymeric composites based on natural fibres," Materials and Design, vol. 48, pp. 14-24, 2013.

[17] A. Brown, "The mechanical properties of fibers," Textile Research Journal, vol. 25, pp. 617-628, 1955.

[18] M. Brahmakumar, C. Pavithran, and R. M. Pillai, "Coconut fibre reinforced polyethylene composites: effect of natural waxy surface layer of the fibre on fibre/matrix interfacial bonding and strength of composites," Composites Science and Technology, vol. 65, no. 3-4, pp. 563-569, 2005.

[19] P. Kenins, "Influence of fiber type and moisture on measured fabric-to-skin friction," Textile Research Journal, vol. 64, no. 12, pp. 722-728, 1994.

[20] U. Nirmal, N. Singh, J. Hashim, S. T. W. Lau, and N. Jamil, "On the effect of different polymer matrix and fibre treatment on single fibre pullout test using betelnut fibres," Materials and Design, vol. 32, no. 5, pp. 2717-2726, 2011.

[21] L. A. Pothan, Z. Oommen, and S. Thomas, "Dynamic mechanical analysis of banana fiber reinforced polyester composites," Composites Science and Technology, vol. 63, no. 2, pp. 283-293, 2003.

[22] N. Sgriccia, M. C. Hawley, and M. Misra, "Characterization of natural fiber surfaces and natural fiber composites," Composites Part A: Applied Science and Manufacturing, vol. 39, no. 10, pp. 1632-1637, 2008.

[23] Z. Leman, S. M. Sapuan, A. M. Saifol, M. A. Maleque, and M. M. H. M. Ahmad, "Moisture absorption behavior of sugar palm fiber reinforced epoxy composites," Materials and Design, vol. 29, no. 8, pp. 1666-1670, 2008.

[24] C. A. Harper, Handbook of Plastics, Elastomers and composites, McGraw Hill Professional Book, New York, NY, USA, 1996. 
[25] F. G. Torres and M. L. Cubillas, "Study of the interfacial properties of natural fibre reinforced polyethylene," Polymer Testing, vol. 24, no. 6, pp. 694-698, 2005.

[26] R. D. Cordes and I. M. Daniel, "Determination of interfacial properties from observations of progressive fiber debonding and pullout," Composites Engineering, vol. 5, no. 6, pp. 633-648, 1995.

[27] S. Narish, B. F. Yousif, and D. Rilling, "Adhesive wear of thermoplastic composite based on kenaf fibres," Proceedings of the Institution of Mechanical Engineers J: Journal of Engineering Tribology, vol. 225, no. 2, pp. 101-109, 2011.

[28] C. W. Chin and B. F. Yousif, "Potential of kenaf fibres as reinforcement for tribological applications," Wear, vol. 267, no. 9-10, pp. 1550-1557, 2009.

[29] M. Bernard, A. Khalina, A. Ali et al., "The effect of processing parameters on the mechanical properties of kenaf fibre plastic composite," Materials and Design, vol. 32, no. 2, pp. 1039-1043, 2011.

[30] T. Nishino, K. Hirao, M. Kotera, K. Nakamae, and H. Inagaki, "Kenaf reinforced biodegradable composite," Composites Science and Technology, vol. 63, no. 9, pp. 1281-1286, 2003.

[31] J.-K. Kim, C. Baillie, and Y.-W. Mai, "Interfacial debonding and fibre pull-out stresses," Journal of Materials Science, vol. 27, no. 12, pp. 3143-3154, 1992.

[32] R. Agrawal, N. S. Saxena, K. B. Sharma, S. Thomas, and M. S. Sreekala, "Activation energy and crystallization kinetics of untreated and treated oil palm fibre reinforced phenol formaldehyde composites," Materials Science and Engineering A, vol. 277, no. 1-2, pp. 77-82, 2000.

[33] X. Li, L. G. Tabil, and S. Panigrahi, "Chemical treatments of natural fiber for use in natural fiber-reinforced composites: a review," Journal of Polymers and the Environment, vol. 15, no. 1, pp. 25-33, 2007.

[34] M. M. Kabir, H. Wang, T. Aravinthan, F. Cardona, and K.-T. Lau, "Effects of natural fibre surface on composite properties: a review," in Energy, Environment and Sustainability, pp. 94-99, 2007.

[35] K. J. Wong, B. F. Yousif, and K. O. Low, "The effects of alkali treatment on the interfacial adhesion of bamboo fibres," Proceedings of the Institution of Mechanical Engineers Part L: Journal of Materials: Design and Applications, vol. 224, no. 3, pp. 139148, 2010.

[36] A. Valadez-Gonzalez, J. M. Cervantes-Uc, R. Olayo, and P. J. Herrera-Franco, "Effect of fiber surface treatment on the fibermatrix bond strength of natural fiber reinforced composites," Composites B: Engineering, vol. 30, no. 3, pp. 309-320, 1999.

[37] B. F. Yousif, S. T. W. Lau, and S. McWilliam, "Polyester composite based on betelnut fibre for tribological applications," Tribology International, vol. 43, no. 1-2, pp. 503-511, 2010.

[38] R. A. Khan, M. A. Khan, H. U. Zaman et al., "Comparative studies of mechanical and interfacial properties between jute and e-glass fiber-reinforced polypropylene composites," Journal of Reinforced Plastics and Composites, vol. 29, no. 7, pp. 1078-1088, 2010.

[39] M. S. Huda, L. T. Drzal, A. K. Mohanty, and M. Misra, "Effect of fiber surface-treatments on the properties of laminated biocomposites from poly(lactic acid) (PLA) and kenaf fibers," Composites Science and Technology, vol. 68, no. 2, pp. 424-432, 2008.

[40] B. F. Yousif and N. S. M. El-Tayeb, "Adhesive wear performance of T-OPRP and UT-OPRP composites," Tribology Letters, vol. 32, no. 3, pp. 199-208, 2008.
[41] M. Rokbi, "Effect of chemical treatment on flexure properties of natural fiber-reinforced polyester composite," Procedia Engineering, vol. 10, pp. 2092-2097, 2011.

[42] A. Oláh and G. J. Vancso, "Characterization of adhesion at solid surfaces: development of an adhesion-testing device," European Polymer Journal, vol. 41, no. 12, pp. 2803-2823, 2005.

[43] U. Nirmal, B. F. Yousif, D. Rilling, and P. V. Brevern, "Effect of betelnut fibres treatment and contact conditions on adhesive wear and frictional performance of polyester composites," Wear, vol. 268, no. 11-12, pp. 1354-1370, 2010.

[44] M. Y. Quek and C. Y. Yue, "An improved analysis for axisymmetric stress distributions in the single fibre pull-out test," Journal of Materials Science, vol. 32, no. 20, pp. 5457-5465, 1997. 

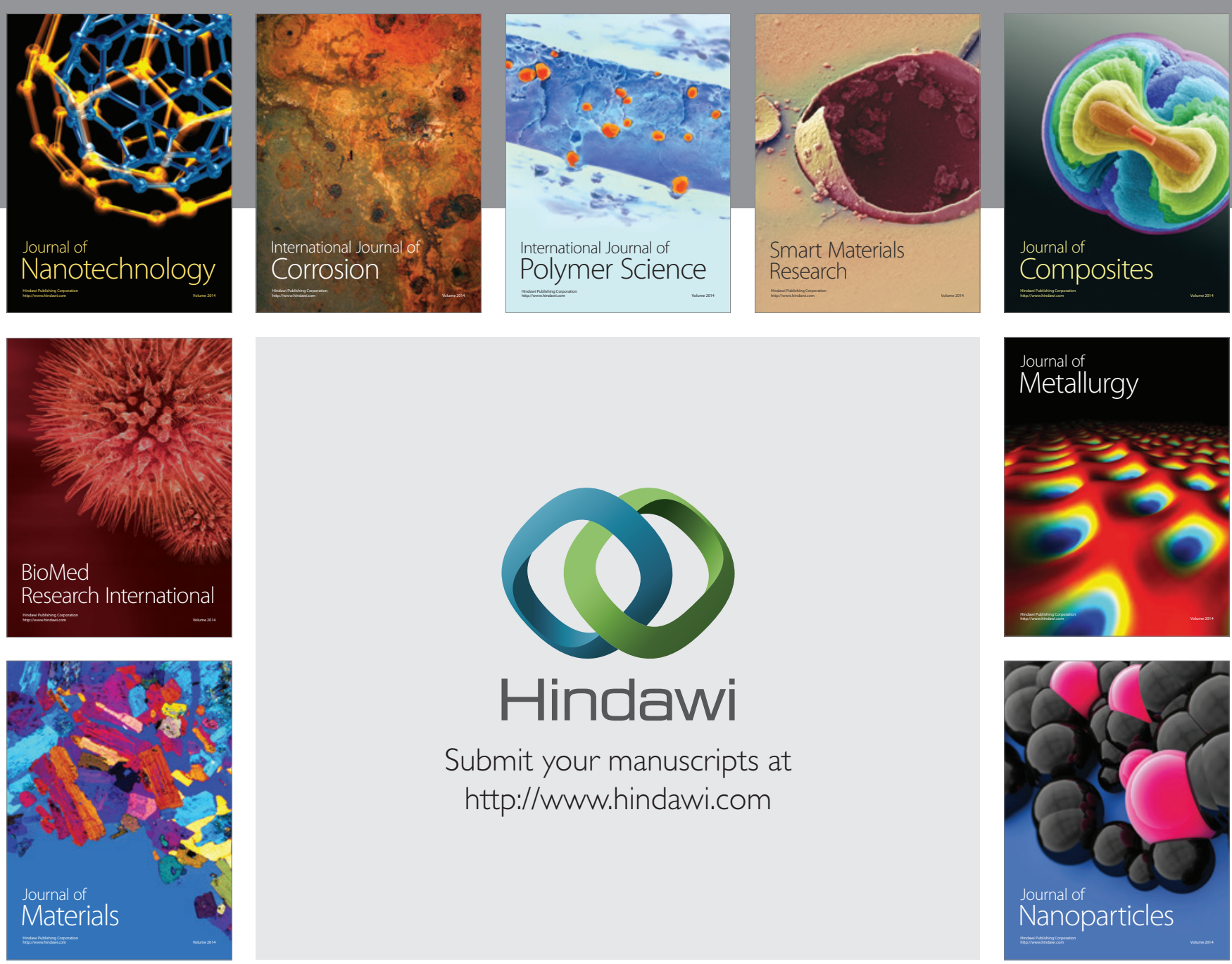

Submit your manuscripts at http://www.hindawi.com
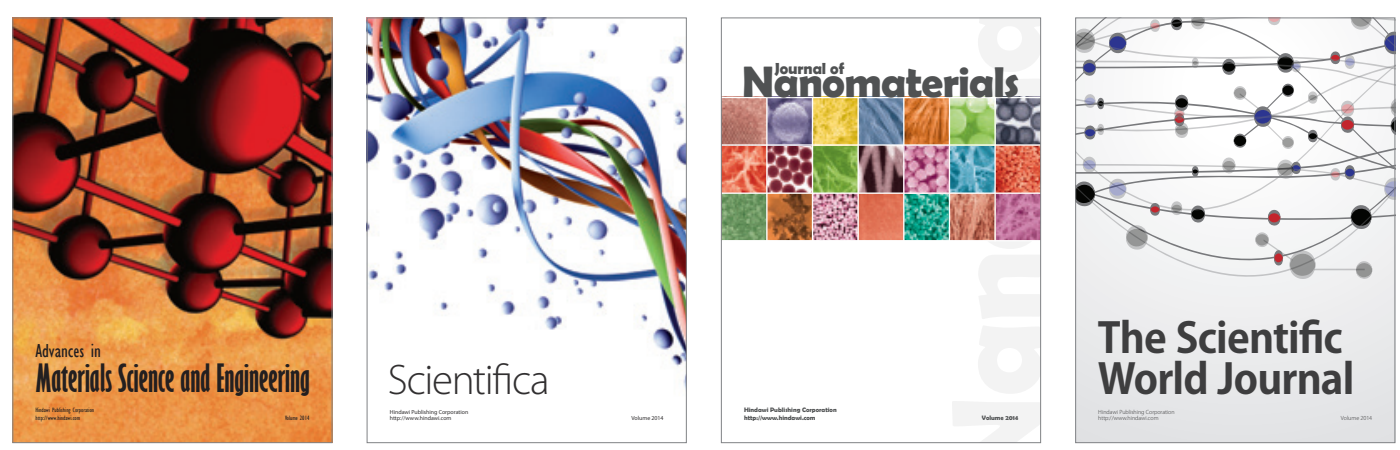

\section{The Scientific World Journal}
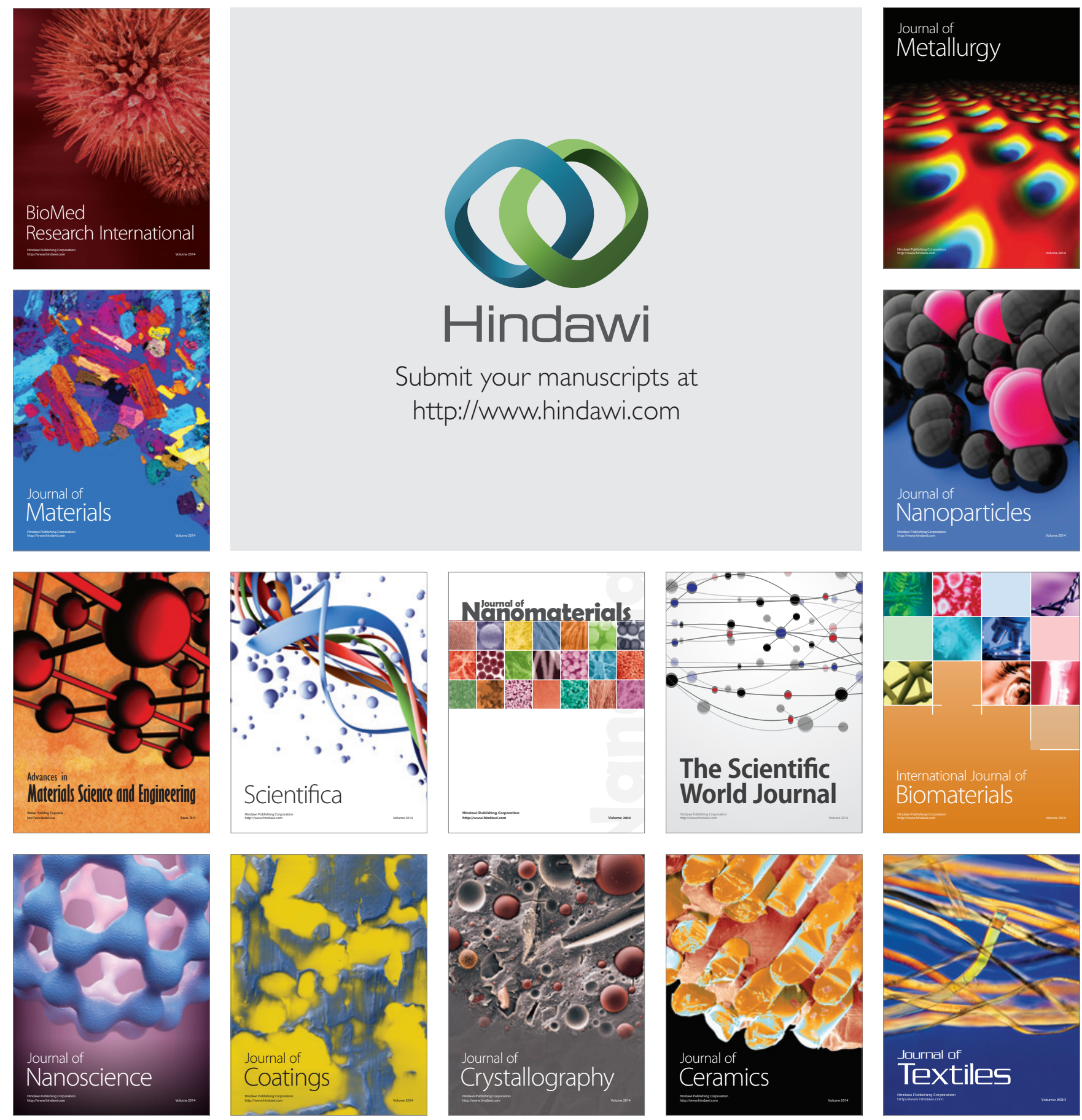